\title{
Leprosy Diagnosis: An Update on the Use of Molecular Tools Lucrecia
}

\section{Acosta Soto* and Pedro Torres Muñoz}

Sanatorium Fontilles, Vall de Laguar, Alicante, Spain

\begin{abstract}
Leprosy is a chronic infectious disease caused by an obligatory intracellular mycobacteria Mycobacterium leprae, which presents tropism for Schwann cells and skin macrophages. Leprosy is a public health problem and early diagnosis is essential to avoid incapacities. The disease's clinical presentation varies from few to widespread lesions and its diagnosis continues to be a challenge due to the low sensibility of the conventional methods, based on bacillary counts of skin smears and histopathology. Molecular techniques, especially the methods to identify M. leprae DNA based on polymerase chain reaction (PCR) have emerged as a support of the conventional methods for the analysis of clinical samples in difficult to diagnose cases, such as pure neural leprosy, indeterminate and paucibacillary leprosy. The technique has also proved useful in the study of leprosy transmission and monitoring résistance to the WHO recommended Multidrug treatment. Different biological samples can be analysed and there is no consensus in the molecular diagnostic techniques respect of the most efficient nucleic acid extraction method, most appropriate methodology and genetic target for PCR. These methods provide a very valuable option for confirmation of difficult clinical cases with scarce bacilli but requires a well-equipped laboratory and the high cost makes it inaccessible to be used as a routine diagnostic tool in most endemic countries.
\end{abstract}

\section{Leprosy diagnosis}

Leprosy is a chronic infectious disease caused by an obligatory intracellular mycobacteria Mycobacterium leprae [1], which presents tropism for Schwann cells and skin macrophages [2,3]. At present, leprosy remains a public health problem. The main strategy to control leprosy is early detection and treatment with multidrug therapy (MDT) [4]. Despite being an ancient disease, known since Biblical times [5], its diagnosis continues to be a challenge due to the low sensibility of the conventional methods and impossibility to culture the bacillus "in vitro". Leprosy develops after an estimated incubation period of 2 to 10 years and presents a complex spectrum of clinical forms [6]. In clinical practice, the diagnosis is mainly based on the observation of clinical symptoms and supported by bacteriological analysis (Zielh-Neelsen smear (ZNS) and histopathology).

A negative ZNS only indicates that the concentration of bacilli is below $10,000 \mathrm{bacilli} / \mathrm{mL}$ [7], and this does not necessarily mean that the person is not infected [8]. This issue is especially problematic for individuals with pure neural leprosy (PNL), indeterminate (IL) and paucibacillary $(\mathrm{PB})$ disease, which harbour a low burden of bacteria. On the other hand, with microscopic visualization all mycobacteria are phenotypically indistinguishable. Moreover, the serological techniques commercially available are inconclusive [9-12].

Many of the methods used in the diagnosis of other mycobacterial infections are not available in leprosy [13]. Research for the development of new diagnostic tools is particularly complicated since the only sources of bacteria are leprosy patients and a natural reservoir, the nine-banded armadillo (Dasypus novemcinctus) $[14,15]$. Thus, studying defined infections in mouse and armadillo models can provide insights into the host-pathogen interactions involved in this complex disease $[16,17]$.

In leprosy, early diagnosis is essential and molecular techniques have emerged as a support of the conventional methods for the analysis of clinical samples. They offer culture-independent methods more sensitive and specific for the identification, confirmation and treatment of the infection, interrupting the chain of transmission and preventing the onset of disabilities $[18,19]$.

\section{M. leprae detection in clinical samples}

Definitive identification of $M$. leprae in clinical specimens using PCR will depend largely on the standardization and other related factors such as the number of copies of the target, the product size and the PCR conditions. Several non-commercial protocols using techniques based on the amplification of different sequences and targets have been developed. The most frequently used for diagnosis are:

Amplifying the gene encoding an $18 \mathrm{kDa}$ antigenic protein by conventional PCR (cPCR) [20-26], with a sensitivity limit of 100 bacilli/sample [22] or of approximately 30 bacilli/sample by nested PCR (nPCR) [27]. Another method targets a gene that encodes an antigenic $36 \mathrm{kDa}$ protein known as proline-rich antigen (pra gen) by cPCR [28-33], and can detect up to a single bacteria in the sample [28]. The pra gen has also been amplified by multiplex PCR (mPCR) [34]. Plikaytis and coworkers, developed a nPCR that amplifies a heat shock protein $65 \mathrm{kDa}$ called groEL, which can detect $3 \mathrm{fg}$ of M. leprae-DNA (single bacteria) [35]. An 85-antigen complex has also been used as a target, which encodes an $85 \mathrm{kDa}$ antigen of three structurally related components [36]; 85B intergenic region by cPCR [37] and for the 85A-C gene by cPCR [37] or quantitative PCR (qPCR) [37-39]. Amplification of specific regions of microsatellites, as well as an internal sequence of the high-affinity manganese transporter (Ml MntH; ML2098) gene of the bacillus can also be useful for detecting M. leprae [40].

Several authors have based their methods on the amplification of specific repetitive sequences of $M$. leprae (RLEP region, 32 repeats per genome) [26,41-43], this technique has undergone modifications and using nPCR can amplify one-tenth of a single bacterial genome [27,4446]. Others have combined PCR and southern hybridization [47-49], mPCR [50] or qPCR [19,38,51-53].

M. leprae can be identified combining PCR of the 16S rDNA internal transcribed spacer (ITS) region with restriction digestion of

${ }^{*}$ Corresponding author: Lucrecia Acosta Soto, Head of Molecular Biology and Investigation Unit, Sanatorium Fontilles. Ctra. Orba-Vall de Laguar, Km 4, 03791 Vall de Laguar, Alicante, Spain, Tel: +34965583350, E-mail: lacosta@fontilles.org

Received September 22, 2015; Accepted October 24, 2015; Published October 31, 2015

Citation: Soto A, Muñoz PT (2015) Leprosy Diagnosis: An Update on the Use of Molecular Tools Lucrecia. Mol Biol 4: 139. doi:10.4172/2168-9547.1000139

Copyright: ( 2015 Soto A, et al. This is an open-access article distributed under the terms of the Creative Commons Attribution License, which permits unrestricted use, distribution, and reproduction in any medium, provided the original author and source are credited. 
the amplified product (restriction fragment length polymorphism (PCR-RFLP)) and its subsequent sequencing [54,55] or by PCR-RFLP amplifying the hsp65 gene [56].

Finally, there are three M. leprae-specific quantitative reverse transcription PCR (rtPCR) assays based on the expression levels of esxA, encoding the ESAT-6 protein [52] and hsp18 [52,57] could enable monitoring of $\mathrm{M}$. leprae viability and amplification of a region belonging to the RNA ribosomal $16 \mathrm{~S}[19,38,58-62]$ which can detect up to 10 viable bacteria in the sample [59].

\section{M. leprae. DNA extraction}

To achieve good results, good sampling, sample processing and DNA extraction is essential [63-66]. The successful amplification of a target sequence depends largely on the amount and quality of the nucleic acids extracted from the biological samples [64]. DNA extraction from clinical samples can be a difficult task, when there are low levels of genomic DNA and/or it is degraded. The mycobacterial cell wall complex has a waterproof structure, which hinders their lysis and subsequent release of the genetic material [67-69]. The efficiency of cell lysis, the ratio of DNA/RNA extracted, and residual extraction reagents will influence this process [69-71]. Other problems that may occur are, contaminants and inhibitors of PCR, the partial degradation of the DNA molecules and the duration of the protocols $[65,72]$.

Procedures commonly used for the isolation of nucleic acids do not obtain good results for M. leprae DNA extraction $[68,73,74]$ and pretreatment steps with: freezing/thawing [75], bead beater with pearls $[27,35]$ proteinase $\mathrm{K}[8,30,66,76]$ minimum 16 hours incubation [33], tris-HCL or tris-EDTA [44], detergents such as triton X-100 [22,77], and SDS $[8,66,76-78]$, alone or in combination should be included.

Additionally, DNA extraction with phenol-chloroform mixture $[66,79]$ can be used to obtain good quality DNA although it has several steps of sample handling, that can reduce performance and increase cross contamination [80]. Several studies have validated the ability of commercial kits: QIAamp DNA Mini Kit and DNeasy Blood \& Tissue Kit (QIAGEN Inc., Valencia, CA) for obtaining both high concentration [79] and good quality DNA with the highest purity value [66] even in samples with highly degraded [72] or scarce DNA [46;79;46].

\section{Suitable samples for M. leprae nucleic acid detection}

The DNA extraction can be performed in different biological samples such as:

Ear lobe and/or lesion lymph: Amplification of $M$. leprae DNA in lymph and slit skin smears has been reported and shown to have advantage over conventional methods $[8,60,66]$. The DNA extraction using these samples can increase both the sensitivity and specificity of the diagnosis and it can also be applied on stained slit skin smears $[27,50,61,76]$ and on a FTA $^{\circ}$ elute card (patented Whatman FTA technology) (Cat no. WB120401; Whatman Inc., Florham Park, N.J., USA) [81]. Patients with negative stained smears can still transmit the infection and molecular culture-independent systems offer techniques to identify and treat them interrupting the chain of transmission and preventing the onset of disabilities $[8,60,66,82]$.

Nasal secretion: Although the route of infection in the human is unknown, upper respiratory tract are considered the main door of entrance and exit of the bacilli in the body [83-86]. Active infected patients (mainly untreated multibacillary patients (MB)) are considered the main source of transmission usually by airborne droplets from nasal and/or mouth [24,87]. The extraction and amplification of $M$. leprae DNA from nasal secretions can be very useful in both screening of potential contacts and leprosy control $[43,49,85,88]$. On the other hand, it has also demonstrated the importance of identifying healthy and subclinical carriers [50,83,84,87,89-92]. In endemic countries, some studies have shown that there are no differences in being a nasal carrier of M. leprae DNA between contacts and non contacts (controls) of a leprosy patient $[83,87]$. But, none of these studies have consistently associated the presence of the $M$. leprae DNA in nasal secretion with further development of the disease: it only indicates nasal carriage, which may imply active leprosy transmission $[43,92]$.

Saliva and oral mucosa: Positive qPCR results suggest the potential usefulness of these two sites for sample collection, especially in paucibacillary patients $[86,39,93] . M$. leprae is present in the oral mucosa at a high frequency, implicating this site as a potential means of leprosy transmission [93]. At the same time, some authors found freeliving bacteria on the oral epithelial surface, with a predilection for the tongue but the results do not correlate with the PCR results [93].

Sputa: Acid-fast bacilli detected by ZNS in sputa and M. tuberculosis complex PCR-negative may need to identified at species level and in some cases $M$. leprae-species can be detected [55].

Whole blood: The $M$. leprae nucleic acid amplification in blood has been conducted in household contacts $[46,49]$, and in post treatment patients and PCR positivity may persist for a period of time (6-8 years) $[32,33,88]$. This type of sample doesn't seem to be a valuable tool for correlating the association of PCR positivity in subclinical stage individuals with the risk for developing late leprosy [49] and some reports have detected that the presence of $M$. leprae in the blood of untreated leprosy patients is infrequent [94,95]. Contacts of multibacillary index cases with a positive PCR in blood are at higher risk of developing leprosy [95]. Others authors, propose their usefulness in whole-blood samples for early detection of leprosy cases [46].

Urine: The use of urine as a diagnosis sample is currently being evaluated [34,96]. The possibility of amplifying the M. leprae DNA in a simple non-invasive sample can be useful and maybe improve the diagnosis mainly in the tuberculoid form or in inconclusive cases where the slit skin smear is usually negative (PNL, IL and PB patients) [34].

Skin biopsy samples: This type of sample increases the possibility of finding bacilli [48], and leprosy molecular diagnosis can be done in: fresh skin biopsies [61], frozen skin biopsies [19,30,33,38,40,44,45,50], in formalin (although is not the appropriate preservative for amplification) [30], paraffin embedded [33,37,53,97], in ethanol $70 \%$ [24], nerve biopsies [98], in post-biopsy swab [33] or filter paper biopsy imprints [40]. An internal control and DNA serial dilutions must be added [66], because this sample is more likely to contain inhibitors of polymerase as: crosslinks between proteins and DNA by formylation of nucleic acids, length of time of fixation in formalin, lengths time of fixation in formalin and impurities form DNA purification can inhibit the polymerase reaction $[22,30,37]$.

\section{Conclusions of leprosy molecular diagnosis}

In clinical practice, the molecular methods are always recommended linked to cases where it is difficult to confirm the diagnosis of leprosy using conventional methods $[19,38,48,87,99-103]$ or in cases where the expected response to treatment is not observed [23,45,104]. PCR diagnosis is initially not necessary for $\mathrm{MB}$ patients with a high bacillary load and a high number of lesions. cPCR assays can remain for long periods of time positive in leprosy patients that have successfully completed their treatment [88]. In these cases it's necessary to estimate bacilli viability using qPCR $[38,57,61]$. It have to consider the objective 
and outcome of employing molecular methods and select the most appropriate and useful techniques for the work.

There is no consensus in the molecular diagnostic techniques respect of the type of specimen or most efficient nucleic acid extraction method, or in the most appropriate methodology and target for PCR. So, the reproducibility between methods and different laboratories cannot be compared, except for the protocols designed to detect $M$. leprae MDT resistance [105]. The sensitivity can be highly variable and the specificity may be compromised according to the handling and methodology employed. The lack of a gold standard test for leprosy makes leprosy diagnosis essentially based on clinical features.

Surveillance of leprosy households and contacts with molecular tools increases the detection rate of less severe clinical presentations with lower bacteriological index $[95,103,106]$ and this is essential for the control of the disease. Although PCR could be a useful tool for the detection of subclinical infection, only a few studies have consistently associated the presence of the $M$. leprae DNA with further development of the disease among household contacts [95].

The definitive identification of $M$. leprae is possible through the development of methods for the extraction, amplification, and identification of M. leprae DNA in clinical specimens using PCR [106]. A few studies have compared several genetic targets $[26,27,38,40,52]$ employing several protocols standardized in small groups of patients $[21,33,58,92]$. The use of a repetitive sequence (RLEP) as a PCR target, provides the advantage of higher sensitivity because it is present at multiple sites in the genomic DNA, especially, in clinical samples, with low concentration of bacilli and/or degraded genomic material (PNL, IL and $\mathrm{PB}$ patients) $[27,38,46,50,51,86]$. The sensitivity of the qPCR and the nPCR were similar for the detection of paucibacillary cases but the $\mathrm{qPCR}$ has the advantage that results can be obtained rapidly and the number of bacilli in the samples estimated [53]. Nevertheless, real-time detection (qPCR) of $M$. leprae did not increase the clinical sensitivity of PCR over that of conventional protocols [107]. The excellent sensitivity and specificity of PCR suggests the test may be useful for the early diagnosis of leprosy but has its limitations for detecting the viability of the bacilli [51].

Overall, the excellent sensitivity and specificity of PCR suggests the technique may be useful and presents an advantage over conventional methods for the early diagnosis of leprosy especially in difficult clinical cases with few bacilli, such as pure neural leprosy, indeterminate and paucibacillary leprosy but has its limitations for detecting the viability of the bacilli [51]. It already has proved useful in M. leprae transmission and resistance to MDT studies and holds promise for detecting $M$. leprae infection before signs of overt disease in high risk groups (household contacts). But it requires a well-equipped laboratory and the high cost makes it inaccessible to be used as a routine diagnostic tool in most endemic countries.

\section{References}

1. Britton WJ, Lockwood DN (2004) Leprosy. Lancet 363: 1209-1219.

2. Shepard CC (1965) Temperature optimum of Mycobacterium leprae in mice. J Bacteriol 90: 1271-1275.

3. Hastings RC, Brand PW, Mansfield RE, Ebner JD (1968) Bacterial density in the skin in lepromatous leprosy as related to temperature. Lepr Rev 39: 71-74.

4. World Health Organization (2015) Weekly epidemiological record 36: 461-476.

5. Hulse EV (1972) Leprosy and ancient Egypt. Lancet 2: 1024-1025.

6. Ridley DS, Jopling WH (1966) Classification of leprosy according to immunity. A five-group system. Int J Lepr Other Mycobact Dis 34: 255-273.

7. Shepard CC, McRae DH (1968) A method for counting acid-fast bacteria. Int $J$ Lepr Other Mycobact Dis 36: 78-82.
8. Kamble RR, Shinde VS, Madhale SP, Kamble AA, Ravikumar BP, et al. (2010) Extraction and detection of Mycobacterium leprae DNA from ZNCF-stained skin smear slides for better identification of negative skin smears. Indian J Med Microbiol 28: 57-59.

9. Spencer JS, Dockrell HM, Kim HJ, Marques MA, Williams DL, et al. (2005) Identification of specific proteins and peptides in Mycobacterium leprae suitable for the selective diagnosis of leprosy. J Immunol 175: 7930-7938.

10. Aráoz R, Honoré N, Cho S, Kim JP, Cho SN, et al. (2006) Antigen discovery: a postgenomic approach to leprosy diagnosis. Infect Immun 74: 175-182.

11. Duthie MS, Truman RW, Goto W, O'Donnell J, et al. (2011) Insight toward early diagnosis of leprosy through analysis of the developing antibody responses of Mycobacterium leprae-infected armadillos. Clin Vaccine Immunol 18: 254-259.

12. Alban SM, de Moura JF, Minozzo JC, Mira MT, Soccol VT (2013) Identification of mimotopes of Mycobacterium leprae as potential diagnostic reagents. BMC Infect Dis 13: 42

13. Domínguez J, Blanco S, Lacoma A, García-Sierra N, Prat C, et al. (2008) [Utility of molecular biology in the microbiological diagnosis of mycobacterial infections]. Enferm Infecc Microbiol Clin 26 Suppl 9: 33-41.

14. Kirchheimer WF, Sanchez RM (1977) Quantitative aspects of leprosy in armadillos. Lepr India 49: 48-53.

15. Scollard DM, Adams LB, Gillis TP, Krahenbuhl JL, Truman RW, et al. (2006) The continuing challenges of leprosy. Clin Microbiol Rev 19: 338-381.

16. Shepard CC (1960) THE EXPERIMENTAL DISEASE THAT FOLLOWS THE INJECTION OF HUMAN LEPROSY BACILLI INTO FOOT-PADS OF MICE. $J$ Exp Med 112: 445-454

17. Adams LB, Pena MT, Sharma R, Hagge DA, Schurr E, et al. (2012) Insights from animal models on the immunogenetics of leprosy: a review. Mem Inst Oswaldo Cruz 107 Suppl 1: 197-208.

18. Dayal R1, Agarwal M, Natrajan M, Katoch VM, Katoch K, et al. (2007) PCR and in-situ hybridization for diagnosis of leprosy. Indian J Pediatr 74: 645-648.

19. Martinez AN, Lahiri R, Pittman TL, Scollard D, Truman R, et al. (2009) Molecular determination of Mycobacterium leprae viability by use of real-time PCR. J Clin Microbiol 47: 2124-2130.

20. Booth RJ, Harris DP, Love JM, Watson JD (1988) Antigenic proteins of Mycobacterium leprae. Complete sequence of the gene for the $18-\mathrm{kDa}$ protein. J Immunol 140: 597-601.

21. Scollard DM, Gillis TP, Williams DL (1998) Polymerase chain reaction assay for the detection and identification of Mycobacterium leprae in patients in the United States. Am J Clin Pathol 109: 642-646

22. Williams DL, Gillis TP, Booth RJ, Looker D, Watson JD (1990) The use of a specific DNA probe and polymerase chain reaction for the detection of Mycobacterium leprae. J Infect Dis 162: 193-200.

23. Williams DL, Gillis TP, Fiallo P, Job CK, Gelber RH, et al. (1992) Detection of Mycobacterium leprae and the potential for monitoring antileprosy drug therapy directly from skin biopsies by PCR. Mol Cell Probes 6: 401-410.

24. Job CK, Jayakumar J, Williams DL, Gillis TP (1997) Role of polymerase chain reaction in the diagnosis of early leprosy. Int $\mathrm{J}$ Lepr Other Mycobact Dis 65: 461-464.

25. Chae GT, Kim MJ, Kang TJ, Lee SB, Shin HK, et al. (2002) DNA-PCR and RT-PCR for the 18-kDa gene of Mycobacterium leprae to assess the efficacy of multi-drug therapy for leprosy. J Med Microbiol 51: 417-422.

26. Kang TJ, Kim SK, Lee SB, Chae GT, Kim JP (2003) Comparison of two different PCR amplification products (the $18-\mathrm{kDa}$ protein gene vs. RLEP repetitive sequence) in the diagnosis of Mycobacterium leprae. Clin Exp Dermatol 28 420-424.

27. Donoghue HD, Holton J, Spigelman M (2001) PCR primers that can detect low levels of Mycobacterium leprae DNA. J Med Microbiol 50: 177-182.

28. Hartskeerl RA, de Wit MY, Klatser PR (1989) Polymerase chain reaction for the detection of Mycobacterium leprae. J Gen Microbiol 135: 2357-2364.

29. de Wit MY, Klatser PR (1988) Purification and characterization of a $36 \mathrm{kDa}$ antigen of Mycobacterium leprae. J Gen Microbiol 134: 1541-1548.

30. de Wit MY, Faber WR, Krieg SR, Douglas JT, Lucas SB, et al. (1991) Application of a polymerase chain reaction for the detection of Mycobacterium leprae in skin tissues. J Clin Microbiol 29: 906-910. 
31. Kampirapap K, Singtham N, Klatser PR, Wiriyawipart S (1998) DNA amplification for detection of leprosy and assessment of efficacy of leprosy chemotherapy. Int J Lepr Other Mycobact Dis 66: 16-21.

32. Lee KS, Youl OK, Wok RY, Suh MH (1994) Detection of Mycobacterium leprae in tissue and blood by polymerase chain reaction. Int $\mathrm{J}$ Lepr Other Mycobact Dis 62: 139-140.

33. Torres P, Camarena JJ, Gomez JR, Nogueira JM, Gimeno V, et al. (2003) Comparison of PCR mediated amplification of DNA and the classical methods for detection of Mycobacterium leprae in different types of clinical samples in leprosy patients and contacts. Lepr Rev 74: 18-30.

34. Caleffi KR, Hirata RD, Hirata MH, Caleffi ER, Siqueira VL, et al. (2012) Use of the polymerase chain reaction to detect Mycobacterium leprae in urine. Braz $J$ Med Biol Res 45: 153-157.

35. Plikaytis BB, Gelber RH, Shinnick TM (1990) Rapid and sensitive detection of Mycobacterium leprae using a nested-primer gene amplification assay. J Clin Microbiol 28: 1913-1917.

36. Rinke de Wit TF, Bekelie S, Osland A, Wieles B, Janson AA, et al. (1993) The Mycobacterium leprae antigen 85 complex gene family: identification of the genes for the 85A, 85C, and related MPT51 proteins. Infect Immun 61: 3642 3647 .

37. Martinez AN, Britto CF, Nery JA, Sampaio EP, Jardim MR, et al. (2006) Evaluation of real-time and conventional PCR targeting complex 85 genes for detection of Mycobacterium leprae DNA in skin biopsy samples from patients diagnosed with leprosy. J Clin Microbiol 44: 3154-3159.

38. Martinez AN, Ribeiro-Alves M, Sarno EN, Moraes MO (2011) Evaluation of qPCR-based assays for leprosy diagnosis directly in clinical specimens. PLoS Negl Trop Dis 5: e1354.

39. Rosa FB, Souza VC, Almeida TA, Nascimento VA, Vásquez FG, et al. (2013) Detection of Mycobacterium leprae in saliva and the evaluation of oral sensitivity in patients with leprosy. Mem Inst Oswaldo Cruz 108: 572-577.

40. Cruz AF, Furini RB, Roselino AM (2011) Comparison between microsatellites and $\mathrm{Ml} \mathrm{MntH}$ gene as targets to identify Mycobacterium leprae by PCR in leprosy. An Bras Dermatol 86: 651-656.

41. Woods SA, Cole ST (1989) A rapid method for the detection of potentially viable Mycobacterium leprae in human biopsies: a novel application of PCR. FEMS Microbiol Lett 53: 305-309.

42. Goulart IM, Cardoso AM, Santos MS, Gonçalves MA, Pereira JE, et al. (2007) Detection of Mycobacterium leprae DNA in skin lesions of leprosy patients by PCR may be affected by amplicon size. Arch Dermatol Res 299: 267-271.

43. Araújo S, Lobato J, Reis Ede M, Souza DO, Gonçalves MA, et al. (2012) Unveiling healthy carriers and subclinical infections among household contacts of leprosy patients who play potential roles in the disease chain of transmission. Mem Inst Oswaldo Cruz 107 Suppl 1: 55-59.

44. Yoon KH, Cho SN, Lee MK, Abalos RM, Cellona RV, et al. (1993) Evaluation of polymerase chain reaction amplification of Mycobacterium leprae-specific repetitive sequence in biopsy specimens from leprosy patients. J Clin Microbio 31: 895-899.

45. Jamil S, Wilson SM, Hacket M, Hussain R, Stoker NG (1994) A colorimetric PCR method for the detection of M. leprae in skin biopsies from leprosy patients. Int J Lepr Other Mycobact Dis 62: 512-520.

46. Wen Y, Xing Y, Yuan LC, Liu J, Zhang Y, et al. (2013) Whole-blood nested-PCR amplification of M. leprae-specific DNA for early diagnosis of leprosy. Am J Trop Med Hyg 88: 918-922.

47. Grosskinsky CM, Jacobs W R, E. Clark-Curtiss J, Bloom B R (1989) Genetic relationships among Mycobacterium leprae, Mycobacterium tuberculosis and candidate leprosy vaccine strains determined by DNA hybridization: identification of an M. leprae-specific repetitive sequence. Infect Immun 57 $1535-1541$.

48. Santos AR, De Miranda AB, Sarno EN, Suffys PN, Degrave WM (1993) Use of PCR-mediated amplification of Mycobacterium leprae DNA in different types of clinical samples for the diagnosis of leprosy. J Med Microbiol 39: 298-304.

49. Almeida EC, Martinez AN, Maniero VC, Sales AM, Duppre NC, et al. (2004) Detection of Mycobacterium leprae DNA by polymerase chain reaction in the blood and nasal secretion of Brazilian household contacts. Mem Inst Oswaldo Cruz 99: 509-511.

50. Banerjee S, Sarkar K, Gupta S, Mahapatra PS, Guha S, et al. (2010) Multiplex
PCR technique could be an alternative approach for early detection of leprosy among close contacts-a pilot study from India. BMC Infect Dis 10: 252.

51. Truman RW, Andrews PK, Robbins NY, Adams LB, Krahenbuhl JL, et al. (2008) Enumeration of Mycobacterium leprae using real-time PCR. PLoS Negl Trop Dis 2: e328.

52. Davis GL, Ray NA, Lahiri R, Gillis TP, Krahenbuhl JL, et al. (2013) Molecula assays for determining Mycobacterium leprae viability in tissues of experimentally infected mice. PLoS Negl Trop Dis 7: e2404.

53. Yan W, Xing Y, Yuan LC, De Yang R, Tan FY, et al. (2014) Application of RLEP real-time PCR for detection of M. leprae DNA in paraffin-embedded skin biopsy specimens for diagnosis of paucibacillary leprosy. Am J Trop Med Hyg 90: 524529 .

54. Roth A, Reischl U, Streubel A, Naumann L, Kroppenstedt RM, et al. (2000) Novel diagnostic algorithm for identification of mycobacteria using genusspecific amplification of the 16S-23S rRNA gene spacer and restriction endonucleases. J Clin Microbiol 38: 1094-1104.

55. Edwards LJ, Price RN, Krause VL, Huffam SE, et al. (2014) Detection of Mycobacterium leprae by PCR testing of sfrom a patient with pulmonary Cryptococcus coinfection in Northern Australia. J Clin Microbiol 52: 3811-3812.

56. Rastogi N, Goh KS, Berchel M (1999) Species-specific identification of Mycobacterium leprae by PCR-Restriction Fragment Length Polymorphism Analysis of the hsp65 Gene. J Clin Microbiol 37: 2016-2019.

57. Lini N, Shankernarayan NP, Dharmalingam K (2009) Quantitative real-time PCR analysis of Mycobacterium leprae DNA and mRNA in human biopsy material from leprosy and reactional cases. J Med Microbiol 58: 753-759.

58. Arnoldi J, Schlüter C, Duchrow M, Hübner L, Ernst M, et al. (1992) Speciesspecific assessment of Mycobacterium leprae in skin biopsies by in situ hybridization and polymerase chain reaction. Lab Invest 66: 618-623.

59. Kurabachew M, Wondimu A, Ryon JJ (1998) Reverse transcription-PCR detection of Mycobacterium leprae in clinical specimens. J Clin Microbiol 36 1352-1356.

60. Jadhav RS, Kamble RR, Shinde VS, Edward S, Edward VK (2005) Use of reverse transcription polymerase chain reaction for the detection of Mycobacterium leprae in the slit-skin smears of leprosy patients. Indian J Lepr 77: 116-127

61. Phetsuksiri B, Rudeeaneksin J, Supapkul P, Wachapong S, Mahotarn K et al. (2006) A simplified reverse transcriptase PCR for rapid detection of Mycobacterium leprae in skin specimens. FEMS Immunol Med Microbiol 48: 319-328.

62. Rudeeaneksin J, Srisungngam S, Sawanpanyalert P, Sittiwakin T, Likanonsaku $S$, et al. (2008) LightCycler real-time PCR for rapid detection and quantitation of Mycobacterium leprae in skin specimens. FEMS Immunol Med Microbiol 54 263-270.

63. Taylor GM, Worth DR, Palmer S, Jahans K, Hewinson RG (2007) Rapid detection of Mycobacterium bovis DNA in cattle lymph nodes with visible lesions using PCR. BMC Vet Res 3: 12.

64. Bachmann L, Däubl B, Lindqvist C, Kruckenhauser L, Teschler-Nicola M, et al (2008) PCR diagnostics of Mycobacterium tuberculosis in historic human long bone remains from 18th century burials in Kaiserebersdorf, Austria. BMC Res Notes 1: 83

65. de Armas Y, Capó V, López L, Mederos L, Díaz R (2011) Comparación de tres métodos de extracción de ADN de tejidos embebidos en parafina. Biotecnol Apl 28: 40-43.

66. Ruiz-Fuentes JL, Díaz A, Entenza AE, Frión Y, Suárez O, et al. (2015) Comparison of Four DNA Extraction Methods for the detection of Mycobacterium leprae from Zielh-Neelsen Stained Microscopic Slides. http:// dx.doi.org/10.1016/j.jmyco.2015.06.005

67. Reischl U (1996) Application of molecular biology-based methods to the diagnosis of infectious diseases. Front Biosci 1: e72-77.

68. Barry CE 3rd, Mdluli K (1996) Drug sensitivity and environmental adaptation of mycobacterial cell wall components. Trends Microbiol 4: 275-281.

69. Kotlowski R, Martin A, Ablordey A, Chemlal K, Fonteyne PA, et al. (2004) One-tube cell lysis and DNA extraction procedure for PCR-based detection of Mycobacterium ulcerans in aquatic insects, molluscs and fish. J Med Microbio 53: 927-933. 
70. Honoré-Bouakline S, Vincensini JP, Giacuzzo V, Lagrange PH, Herrmann JL (2003) Rapid diagnosis of extrapulmonary tuberculosis by PCR: impact of sample preparation and DNA extraction. J Clin Microbiol 41: 2323-2329.

71. Amita J, Vandana T, Guleria RS, Verma RK (2002) Qualitative Evaluation of Mycobacterial DNA Extraction Protocols for Polymerase Chain Reaction. Mol Biol Today 3: 43-50.

72. Phillips K, McCallum N, Welch L (2012) A comparison of methods for forensic DNA extraction: Chelex-100® and the QIAGEN DNA Investigator Kit (manual and automated). Forensic Sci Int Genet 6: 282-285.

73. Kolk AH, Schuitema AR, Kuijper S, van Leeuwen J, Hermans PW, et al (1992) Detection of Mycobacterium tuberculosis in clinical samples by using polymerase chain reaction and a nonradioactive detection system. $\mathrm{J}$ Clin Microbiol 30: 2567-2575.

74. Fries JW, Patel RJ, Piessens WF, Wirth DF (1991) Detection of untreated mycobacteria by using polymerase chain reaction and specific DNA probes. J Clin Microbiol 29: 1744-1747.

75. Via LE, Falkingham JO (1995) Comparision of methods for isolation of Mycobacterium avium complex DNA for use in PCR and RAPD. J Microbio Meth 26: 151-161.

76. Fontes A, Gomes H, de Araujo M, Albuquerque EC, Baptista IM, et al (2012) Genotyping of Mycobacterium leprae present on Ziehl-Neelsen-stained microscopic slides and in skin biopsy samples from leprosy patients in different geographic regions of Brazil. Mem Inst Oswaldo Cruz 107: 143-149.

77. Awua AK, Doe ED, Gyamfi OK (2010) Evaluation of cost-effective total nucleic acids extraction protocols for cultured Mycobacterium tuberculosis; a comparison by PCR amplification of genes associated with drug resistance. BMC Res Notes 3: 48.

78. Huijsmans CJ, Damen J, van der Linden JC, Savelkoul PH, Hermans MH (2010) Comparative analysis of four methods to extract DNA from paraffinembedded tissues: effect on downstream molecular applications. BMC Res Notes 3: 239.

79. Okwumabua O, Shull E, O'Connor M, Moua T, Danz T, et al. (2010) Comparison of three methods for extraction of Mycobacterium avium subspecies paratuberculosis DNA for polymerase chain reaction from broth-based culture systems. J Vet Diagn Invest 22: 67-69.

80. Sidorova JV, Biderman BV, Nikulina EE, Sudarikov AB (2012) A simple and efficient method for DNA extraction from skin and paraffin-embedded tissues applicable to T-cell clonality assays. Exp Dermatol 21: 57-60.

81. Aye KS, Matsuoka M, Kai M, Kyaw K, Win AA, et al. (2011) FTA card utility for PCR detection of Mycobacterium leprae. Jpn J Infect Dis 64: 246-248.

82. Suárez O, Suffys P, Entenza A, Ruiz J, de Armas Y (2012). Extracción de ADN Revista de Leprología 28: 455-458.

83. Pattyn SR, Ursi D, leven M, Grillone S, Raes V (1993) Detection of Mycobacterium leprae by the polymerase chain reaction in nasal swabs of leprosy patients and their contacts. Int J Lepr Other Mycobact Dis 61: 389-393.

84. Beyene D, Aseffa A, Harboe M, Kidane D, Macdonald M, et al. (2003) Nasal carriage of Mycobacterium leprae DNA in healthy individuals in Lega Robi village, Ethiopia. Epidemiol Infect 131: 841-848.

85. Patrocínio LG, Goulart IM, Goulart LR, Patrocínio JA, Ferreira FR, et al (2005) Detection of Mycobacterium leprae in nasal mucosa biopsies by the polymerase chain reaction. FEMS Immunol Med Microbiol 44: 311-316.

86. Martinez TS, Figueira MM, Costa AV, Gonçalves MA, Goulart LR, et al. (2011) Oral mucosa as a source of Mycobacterium leprae infection and transmission, and implications of bacterial DNA detection and the immunological status. Clin Microbiol Infect 17: 1653-1658.

87. de Wit MY, Douglas JT, McFadden J, Klatser PR (1993) Polymerase chain reaction for detection of Mycobacterium leprae in nasal swab specimens. J Clin Microbiol 31: 502-506.

88. Santos AR, Balassiano V, Oliveira ML, Pereira MA, Santos PB, et al. (2001) Detection of Mycobacterium leprae DNA by polymerase chain reaction in the blood of individuals, eight years after completion of anti-leprosy therapy. Mem Inst Oswaldo Cruz 96: 1129-1133.

89. Klatser PR, van Beers S, Madjid B, Day R, de Wit MY (1993) Detection of Mycobacterium leprae nasal carriers in populations for which leprosy is endemic. J Clin Microbiol 31: 2947-2951.

90. van Beers SM, Izumi S, Madjid B, Maeda Y, Day R, et al. (1994) An epidemiological study of leprosy infection by serology and polymerase chain reaction. Int J Lepr Other Mycobact Dis 62: 1-9.

91. Hatta M, van Beers SM, Madjid B, Djumadi A, de Wit MY, et al. (1995) Distribution and persistence of Mycobacterium leprae nasal carriage among a population in which leprosy is endemic in Indonesia. Trans R Soc Trop Med Hyg 89: 381-385.

92. Lavania M, Turankar RP, Karri S, Chaitanya VS, Sengupta U, et al. (2013) Cohort study of the seasonal effect on nasal carriage and the presence of Mycobacterium leprae in an endemic area in the general population. Clin Microbiol Infect 19: 970-974.

93. Morgado de Abreu MA, Roselino AM, Enokihara M, Nonogaki S, PrestesCarneiro LE, et al. (2014) Mycobacterium leprae is identified in the oral mucosa from paucibacillary and multibacillary leprosy patients. Clin Microbiol Infect 20: 59-64.

94. Lane JE, Balagon MV, Dela Cruz EC, Abalos RM, Tan EV, et al. (2006) Mycobacterium leprae in untreated lepromatous leprosy: more than skin deep. Clin Exp Dermatol 31: 469-470.

95. Reis EM, Araujo S, Lobato J, Neves AF, Costa AV, et al. (2014) Mycobacterium leprae DNA in peripheral blood may indicate a bacilli migration route and highrisk for leprosy onset. Clin Microbiol Infect 20: 447-452.

96. Parkash O, Singh HB, Rai S, Pandey A, Katoch VM, et al. (2004) Detection of Mycobacterium leprae DNA for $36 \mathrm{kDa}$ protein in urine from leprosy patients: a preliminary report. Rev Inst Med Trop Sao Paulo 46: 275-277.

97. Sung KJ, Kim SB, Choi JH, Koh K, Na DS (1993) Detection of Mycobacterium leprae DNA in formalin-fixed, paraffin-embedded samples from multibacillary and paucibacillary leprosy patients by polymerase chain reaction. Int $\mathrm{J}$ Dermatol 32: 710-713.

98. Jardim MR, Antunes SL, Santos AR, Nascimento OJ, Nery JA, et al. (2003) Criteria for diagnosis of pure neural leprosy. J Neurol 250: 806-809.

99. Kaur B y Handa F (1986) Correlation of bacillaemia with clinical types of leprosy. Int J Derm Vener Lepr 52: 272-274.

100. Gillis TP, Williams DL (1991) Polymerase chain reaction and leprosy. Int J Lepr Other Mycobact Dis 59: 311-316.

101. Ayliffe PR (1992) Modern sensitive techniques for the detection of Mycobacterium leprae. Int J Lepr Other Mycobact Dis 60: 451-464.

102. Santos AR1, Goes Filho JT, Nery JA, Duppre NC, Gallo ME, et al. (1995) Evaluation of PCR mediated DNA amplification in non-invasive biological specimens for subclinical detection of Mycobacterium leprae. FEMS Immunol Med Microbiol 11: 113-120.

103. Hacker MA1, Sales AM, Illarramendi X, Nery JA, Duppre NC, et al. (2012) A profile of patients treated at a national leprosy outpatient referral clinic in Rio de Janeiro, Brazil, 1986-2007. Rev Panam Salud Publica 31: 485-491.

104. Rafi A1, Donoghue HD, Stanford JL (1995) Application of polymerase chain reaction for the detection of Mycobacterium leprae DNA in specimens from treated leprosy patients. Int J Lepr Other Mycobact Dis 63: 42-47.

105. World Health Organization Regional Office four South-East Asia (2009) Guidelines for Global Surveillance of Drug Resistance in Leprosy. SEA-GLP 2009-2: 1-32.

106. Martinez AN1, Talhari C2, Moraes MO1, Talhari S3 (2014) PCR-based techniques for leprosy diagnosis: from the laboratory to the clinic. PLoS Negl Trop Dis 8: e2655.

107. Kramme S1, Bretzel G, Panning M, Kawuma J, Drosten C (2004) Detection and quantification of Mycobacterium leprae in tissue samples by real-time PCR. Med Microbiol Immunol 193: 189-193. 